\title{
Revisited Formation of Morphological Features of Gray Forest Soils of West Siberia
}

\author{
Kastornova Marina \\ Department of Soil Science and Agrochemistry, \\ Federal State Budgetary Educational \\ Institution of Higher Education \\ «Northern Trans-Ural State Agricultural University» Tyumen, Russia \\ soil-tyumen@yandex.ru
}

\begin{abstract}
Topsoils of Western Siberia have not been studied in sufficient detail. The causes of it are a variability of soil formation rocks, specifics of relief in the territory, human activities, and inaccessibility of some territories. When moving to precise agriculture, lack of exact information on typology of soils impedes development of zoned soil treatment and fertilizing systems. The goal of the research was to analyze morphological attributes of gray forest soils formed in the forest-steppe zone of Trans-Ural. The paper gives data from multi-year research conducted by the Department of Soil Science and Agricultural Chemistry of the Northern Trans-Ural State Agrarian University collected in the south of Tyumen oblast. It has been established, that subtypes of the gray forest soils differ significantly with each other by their genetic horizons. In light-gray and gray forest soils, there is an eluvial horizon that varies in coloration and structure. Dark-gray forest soils lack this horizon. The attributes of podsolization are evident in ample silica powdering in the lower part of the humus horizon. The soil profile of the dark gray forest soil is closest to chernozems of Trans-Ural forest-steppe in their morphogenetic attributes. Variance and statistical analysis of data from 75 soil profile cuts show a significant variation in depth of the genetic horizons within each subtype of gray forest soils. It impedes classification of the regional soils. Variance in the depth of illuvial carbonate horizon against the background of podsolization and solodization of soils has a significant influence over the soil formation process by forming regional morphogenetic attributes that impede classification of the gray forest soils. When moving to the precise agriculture it is necessary to compile a detailed map of land use that will reflect such regional features of the gray forest soils as the humus horizon depth, presence of podsolization and solodization evidence, carbonate horizon depth. It will give a possibility to develop a system of extended regeneration of fertility of gray forest soils when involving them into the plowed stock of Western Siberia.
\end{abstract}

Keywords-Western Siberia, soil formation, gray forest soil, morphological attributes, soil profile, genetic horizons.

\section{INTRODUCTION}

Gray forest soils take the third place in the soil cover of Western Siberia, after podzolic and boggy soils. Gray forest soils are usually found in large masses, making them the most promising for agricultural use. They are found together with grassland soils and chernozems. That is why they were plowed in Western Siberia, just like the fertile soils. It is especially true of the dark gray forest soil subtype, soils of which are currently rare in virgin state.

Agriculture in Western Siberia and Ural Federal District develops, in particular, by using best practices and discoveries in land use, selection and agrochemistry. Currently, there are scientifically-grounded systems of fertilization, crop rotation and soil management $[1,2,3]$. Siberian plant breeders have created crop varieties capable of high yields of high-quality produce under unfavorable climatic conditions. [4, 5, 6]. However, movement to the precise agriculture system turned out problematic, as agrarians do not have enough knowledge about properties of soil in their fields. It leads to unwanted consequences, such as lower productivity of plowed land and deterioration of soil fertility. It must be acknowledged, that while working for decades on the land we often have no idea about what kind of soil it is and what is its development path. Detailed study of morphological properties make it possible to positively classify the soil and develop a system of its rational use in the national economy.

With the development of digital technologies and IT, there is a possibility to systematize vast volumes of primary information on morphogenetic attributes and main properties of soils [7]. It gives an opportunity to model soil formation processes and predict fertility of new potting soils having the characteristics of the natural soils from a certain region $[8,9]$

The soil cover in the south of Tyumen oblast is still not studied in sufficient detail, despite the long-term work of soil studying expeditions organized by the North Trans-Ural R\&D Institute, agrochemical services of Tyumen oblast and the Agricultural University. This is due to a wide variety of soil forming rocks, complexity of relief, anthropogenic factor and vegetation. Currently, it is widely accepted that in Western Siberia as a whole and in the south of Tyumen oblast in particular, soil formation processes are superimposed, thus forming specific attributes and properties that are not found in soils of other regions. Gray forest soils turned out to be the most variable. Besides classical morphological attributes, this soils often have specific ones, appearing due to solodization and podsolization against the background of constant or shortterm waterlogging. Regional climatic features also play their role in formation of the gray forest soils, which is reflected in changes in thickness of genetic horizons and their ratios. 
Research objective: Establishing regional morphological features of gray forest soils of West Siberia.

\section{SUBJECTS AND METHODS}

The paper gives data on soil profiles in subtaiga and foreststeppe zones of Trans-Ural in the territory of Tyumen oblast. The studies were conducted only on virgin lands under forests of various taxonomy. The soil cuts were made for the whole depth down to the soil forming rock. Diagnostics and classification of the soils were performed according to Field Guide to Soils of Russia [10]. We studied the morphogenetic attributes of all the subtypes of the gray forest soil. During the period from 1997 to 2017, 75 full-profile cuts were made (depth of $2.0 \mathrm{~m}$ ) as well as 80 half-pits with a depth of up to 1.0 meter. Statistic processing of the results was performed according to the method of B.A. Dospekhov, using Microsoft Excel.

\section{RESULTS}

Gray forest soils are common mostly in the northern part of the forest-steppe zone. Together with gray forest gley soils, they take up the area of over 50 million hectare, or about $2.3 \%$ of all the soils in the country by area. Among the zonal soils of Tyumen oblast, gray forest soils are the second most common, after podzolic soils. In total, they cover about $6.3 \%$ of the territory of the southern Tyumen oblast. The total area of the gray forest soils in the oblast amounts to 880 thousand hectare, while chernozems take up just over 500 thousand hectare [11, $12,13]$. The main areas are located in the forest-steppe zone and in the sub-taiga subzone (some may be found in the south of southern taiga). They are linked to the most drained areas of the region. They are located at high undulating terraces of large rivers, as well as in valleys of small rivers and brooks with various types of ravine systems. Gray forest soils are usually found in large masses. In the subtaiga subzone, they are combined or border with grassland or grasslandchernozem or humus-podzolic soils, while in the forest-steppe zone they are more often combined with chernozems and grassland chernozems, and less often with grassland and solonchak soils.

Gray forest soils of Western Siberia are mainly covered with birch and aspen forests with well-developed grassy vegetation, whose ratio increases as the forest becomes more open. In the shrub layer, mountain ash and rosehip prevail; in the at-ground level, there are various grasses and motley grass associations. Leguminous grasses are quite common. Among gramineals, the most common are reed grass (Calamagrostis lanceolata L.); bent grass (Agrostis stolonifera L.); timothy (Phleum pratense L.); meadow grass (Poa pratensis L); awnless brome (Bromus inermis L.). Among motley grasses, the most common are dropwort (Filipendula vulgaris MOENCH.); elecampane (Inula L.); milfoil (Achillea millefolium L.); wood crane (Geranium sylvaticum L.); strawberry. Of pulses, one may find clover (Trifolium); cow wetch (Vicia cracca L.); craw pea (Lathyrus pratensis L.).

Thanks to deciduous forest allowing more light through than coniferous one, the soil surface is almost completely covered with herbaceous vegetation. In the upper part of the soil profile a weakly developed grassy turf is formed $\left(\mathrm{A}_{0}\right)$, whose thickness together with the litter fall in light gray forest soil is on average $3 \mathrm{~cm}$ (Table 1). In a dense forest, $A_{0}$ usually consists of leaf litter, whose layer may reach $5 \mathrm{~cm}$ in thickness.

TABLE I. VARIATION AND STATISTICAL INDICATORS OF THE DEPTH OF GENETIC HORIZONS OF GRAY FOREST SOILS OF WEST SIBERIA

\begin{tabular}{|c|c|c|c|c|c|c|}
\hline \multirow[b]{2}{*}{ Soil subtype } & \multirow[b]{2}{*}{$\begin{array}{c}\text { Indicator } \\
\mathrm{s} \\
\end{array}$} & \multicolumn{5}{|c|}{ Genetic horizons } \\
\hline & & AO & $A 1$ & $\begin{array}{l}A 1 A 2 \\
(A 2 B)\end{array}$ & $B$ & $B_{K}$ \\
\hline \multirow{4}{*}{$\begin{array}{l}\text { Light-gray } \\
\text { forest }(n=30)^{*}\end{array}$} & Min, $\mathrm{cm}$ & 3 & 12 & 8 & 42 & 25 \\
\hline & Max, cm & 5 & 18 & 15 & 64 & 34 \\
\hline & $\begin{array}{l}\text { Average, } \\
\mathrm{cm}\end{array}$ & 3 & 15 & 12 & 50 & 30 \\
\hline & $\mathrm{CV}, \% * *$ & 7 & 18 & 15 & 20 & 15 \\
\hline \multirow{4}{*}{$\begin{array}{l}\text { Gray } \\
(n=45)\end{array}$} & Min, $\mathrm{cm}$ & 3 & 15 & 5 & 57 & 38 \\
\hline & Max, cm & 5 & 27 & 12 & 88 & 44 \\
\hline & $\begin{array}{l}\text { Average, } \\
\mathrm{cm}\end{array}$ & 4 & 22 & 7 & 80 & 41 \\
\hline & $\mathrm{CV}, \%$ & 10 & 25 & 17 & 25 & 18 \\
\hline \multirow{4}{*}{$\begin{array}{l}\text { Dark gray forest } \\
(n=80)\end{array}$} & Min, $\mathrm{cm}$ & 2 & 24 & - & 48 & 35 \\
\hline & Max, cm & 4 & 38 & - & 134 & 52 \\
\hline & $\begin{array}{l}\text { Average, } \\
\mathrm{cm}\end{array}$ & 4 & 28 & - & 95 & 44 \\
\hline & $\mathrm{CV}, \%$ & 5 & 14 & - & 17 & 10 \\
\hline
\end{tabular}

With reduction of forest stand density, the share of herbs found on dark gray forest soil increases significantly. Pulses appear, which significantly enrich the soil with nitrogen, thus intensifying microbiological activity that decomposes plant residues. On average, the thickness of the grassy turn is $4 \mathrm{~cm}$; it is represented with tightly woven roots of perennial herbs with a minor admixture of leaf litter.

Gray forest soils are formed in a combination of sodforming and podzolic processes, the rate of which depends on forest density, as it regulates the herbaceous cover development and its botanic composition [14, 15, 16]. Taking into account that there are forests of various age in Western Siberia, thickness of their genetic horizons varies significantly. As a whole, profiles of these soils are sharply differentiated into a number of genetic horizons, whose thickness influences the agricultural use direction.

Humus-eluvial horizon $\left(\mathrm{A}_{1}\right)$ of gray soils is not too large in comparison with their European analogs. Usually, harsh climate in the region is held as a cause, as it prevents root systems from completely utilizing the top layers. On average, light gray forest soil have $A_{1}$ horizon of a thickness of $15 \mathrm{~cm}$ with a variation coefficient of $18 \%$. Maximum thickness of this horizon for light gray forest soils never exceeds $18 \mathrm{~cm}$.

A subtype of gray forest soils is characterized with a high degree of variation in thickness of the humus-eluvial horizon $(\mathrm{CV}=22 \%)$. Its spread is from 15 to $27 \mathrm{~cm}$, with $22 \mathrm{~cm}$ as an average. This high level of variance is caused by relief and anthropogenic factor that radically changes contemporary soil 
formation process (clearing of forests, plowing, moving of plowed land to fallow).

The thickness of humus-eluvial horizon $\left(\mathrm{A}_{1}\right)$ and its humus content put dark gray forest soils next to forest-steppe chernozems of Trans-Urals [17, 18, 19]. In the south of Tyumen oblast until now one may find areas of dark gray forest soils where humus layer reaches $38 \mathrm{~cm}$. Each year there are less and less such soils, as they are actively involved into regional plowed land stock. On average, the humus-eluvial horizon of the dark gray forest soils is $28 \mathrm{~cm}$; the minimal value observed was $24 \mathrm{~cm}$.

The humus-eluvial horizon has coloration from light to dark gray, sometimes almost black, depending on subtype. The structure is cloddy or lumpy-powder-like. The horizon is loose or lightly compacted. When putting gray forest soils under plow, the attributes of the humus-eluvial horizon change, while physical, chemical and hydrochemical properties deteriorate. It has a negative impact on supply of nutrients and fertility of soils [20,21].

Full-scale eluvial horizon is never seen even in light gray forest soils. So-called transitional horizons $\mathrm{A}_{1} \mathrm{~A}_{2}$ and $\mathrm{A}_{2} \mathrm{~B}$ are also identified, which are usually called eluvial . $A_{1} A_{2}$ is characterized with light gray or pale gray coloration, puddled structure and cloddy platelet structure. Under dense forests, where the sod process is not expressed due to lack of herbaceous plants, the structure of the $A_{1} A_{2}$ horizon may be platelet or lacking totally. More often, this horizon is found in light gray forest soils and its thickness varies from 8 to $15 \mathrm{~cm}$. Horizon $\mathrm{A}_{2} \mathrm{~B}$ is characterized with a brownish light gray coloration and usually is found in the subtype of gray forest soils. Its thickness is on average from 5 to $12 \mathrm{~cm}$, the average is $7 \mathrm{~cm}$.

In dark gray forest soils these horizons do not appear, and the only attribute of podzolization is ample silicon earth powdering in the lower part of the humus horizon. Usually this horizon is designated as $\mathrm{A}_{1} \mathrm{~B}$, thus marking past podzolization. Currently, it is impossible to say anything definitive on podzolization manifestation in dark gray forest soils, as nearby carbonate horizons and a change of climate to increased aridization prevents the acidification process. Horizon $A_{1} B$ is characterized with a brown gray coloration with brownish hue and cloddy-nutty structure of soil.

Illuvial horizon (B) is clearly differentiated thanks to its brown or dark brown coloration, dense composition and nutty structure. These attributes are used to divide the horizon into $\mathrm{B} 1 ; \mathrm{B}_{2}$ and $\mathrm{B}_{3}$. The average thickness of illuvial horizon in light gray forest soils is $50 \mathrm{~cm}$, varying from 42 to $64 \mathrm{~cm}$. In dark gray forest soils, the illuviation covers almost one and a half meter, while the variation coefficient of $17 \%$ indicates non-uniformness of the illuvial horizon thickness in the south of Tyumen oblast. For light gray and gray forest soils, variation is $20 \%$ and $25 \%$ respectively, determining unstable nature of fertility indicators.

In the upper part of the illuvial horizon (B), a silica earth powdering is found. Aggregates often have glossy appearance on the facets, which is an attribute of relict solodization. At that, it is necessary to note, that these attributes are often seen even in light gray forest soils, where the podzolization process happens to the full extent. In the middle or lower part of the horizon there are newly formed carbonates in the form of spots, small-scale flakes, loess dolls. The boiling depth across the type is $68-117 \mathrm{~cm}$, which corresponds to chernozems and determines large differences in fertility of gray forest soils even within the same subtype.

Parent rock (C) is of light or yellow brown coloration, or otherwise straw-yellow-brown coloration. It is less dense than the overlying Вк horizon and the structure is unpronounced. Here, and sometimes above, traces of past or present gleization are found in the form of rusty ochreous formations or blue-gray spots, which are evidences of variable moistening.

As an example, here we give a morphologic description of gray forest soil subtypes with the attributes and properties most common in Western Siberia.

\section{TABLE II. SOIL SECTION 1. LIGHT-GRAY FOREST PODZOLIC, LIGHT LOAM, ON THE SURFACE LOAM. BIRCH FOREST. HERBACEOUS VEGETATION IS ABSENT}

\begin{tabular}{|l|l|}
\hline $\begin{array}{c}\text { Horizon, depth, } \\
\text { cm }\end{array}$ & \multicolumn{1}{|c|}{ Morphological attributes of the horizon } \\
\hline $\mathrm{A}_{0} 0-2 \mathrm{~cm}$ & Forest litter. \\
\hline $\mathrm{A}_{1} 2-13 \mathrm{~cm}$ & $\begin{array}{l}\text { Dry, light gray, lumpy-powder-like soil, loose, roots of } \\
\text { woody plants, light loamy soils. Gradual transition. }\end{array}$ \\
\hline $\mathrm{A}_{1} \mathrm{~A}_{2} 13-17 \mathrm{~cm}$ & $\begin{array}{l}\text { Dry, light gray with hoary hue, platelet, lightly } \\
\text { compacted, fine-porous, roots, light loamy. Transition is } \\
\text { noticeable. }\end{array}$ \\
\hline $\mathrm{B}_{1} 17-68 \mathrm{~cm}$ & $\begin{array}{l}\text { Fresh, dark brown, nutty, dense, fine porous, silica earth } \\
\text { powdering on facets of aggregates, roots, light loamy. } \\
\text { Transition is clear. }\end{array}$ \\
\hline $\mathrm{B}_{2} 68-115 \mathrm{~cm}$ & $\begin{array}{l}\text { Light, brown, coarsely nutty structure, dense, fine } \\
\text { porous, black-brown inclusions, roots, light loamy. } \\
\text { Gradual transition. }\end{array}$ \\
\hline $\mathrm{C}>115 \mathrm{~cm}$. & $\begin{array}{l}\text { Fresh, light brown, instable nutty, compacted, roots, } \\
\text { black-brown inclusions. }\end{array}$ \\
\hline
\end{tabular}

TABLE III. SOIL SECTION 2. ABSOLUTELY GRAY FOREST, MEDIUM LOAMY ON LOESS-LIKE LOAM-BIRCH FOREST.

\begin{tabular}{|l|l|}
\hline \multicolumn{1}{|c|}{$\begin{array}{c}\text { Horizon, } \\
\text { depth, cm }\end{array}$} & \multicolumn{1}{c|}{ Morphological attributes of the horizon } \\
\hline $\mathrm{A}_{0} 0-3 \mathrm{~cm}$ & Radiculous grassy turf, loose \\
\hline $\mathrm{A}_{1} 3-16 \mathrm{~cm}$ & $\begin{array}{l}\text { Fresh, gray, small-scale cloddy, weakly compacted, } \\
\text { lots of roots, middle loamy, gradual transition. }\end{array}$ \\
\hline $\mathrm{A}_{2} \mathrm{~B} 16-26 \mathrm{~cm}$ & $\begin{array}{l}\text { Fresh, light gray with a brown hue, fine nutty, weakly } \\
\text { compacted, lots of roots, medium loamy, clear } \\
\text { transition. }\end{array}$ \\
\hline $\mathrm{B}_{2} 26-58 \mathrm{~cm}$ & $\begin{array}{l}\text { Fresh, dark brown, fine nutty, compacted, humus } \\
\text { lacquer and silicon earth powdering on facets of } \\
\text { aggregate, roots, heavy loamy, gradual transition. }\end{array}$ \\
\hline $\mathrm{B}_{3} 58-100 \mathrm{~cm}$ & $\begin{array}{l}\text { Fresh, dark brown, nutty, very dense, humus lacquer on } \\
\text { facets of aggregate, roots, root impressions, heavy } \\
\text { loamy, transition is clear. }\end{array}$ \\
\hline $\mathrm{B}_{\mathrm{Ca}} 100-140 \mathrm{~cm}$ & $\begin{array}{l}\text { Fresh, light brown with a straw hue, unstructured, } \\
\text { dense, boiling, carbonate inclusions with a diameter up } \\
\text { to 4 mm, heavy loamy, gradual transition. }\end{array}$ \\
\hline $\mathrm{C}_{\mathrm{Ca}}>140 \mathrm{~cm}$ & $\begin{array}{l}\text { Fresh, yellow brown, unstructured, compacted, rogue } \\
\text { roots, carbonate of various forms, heavy loamy }\end{array}$ \\
\hline
\end{tabular}


TABLE IV. SOIL SECTION 3. DARK ABSOLUTELY GRAY FOREST, MEDIUM LOAMY ON LOESS CARBONATE LOAM. ADULT BIRCH FOREST, WELL DEVELOPED GRASSY COVER.

\begin{tabular}{|l|l|}
\hline \multicolumn{1}{|c|}{$\begin{array}{c}\text { Horizon, } \\
\text { depth, cm }\end{array}$} & \multicolumn{1}{c|}{ Morphological attributes of the horizon } \\
\hline $\mathrm{A}_{0} 0-2 \mathrm{~cm}$ & Well-developed grassy turf. Leaf litter is insignificant. \\
\hline $\mathrm{A}_{1} 2-27 \mathrm{~cm}$ & $\begin{array}{l}\text { Fresh, black, cloddy, loose, pierced with roots, silicon } \\
\text { earth powdering in the lower part, medium loamy. } \\
\text { Gradual transition. }\end{array}$ \\
\hline $\mathrm{B}_{1} 27-59 \mathrm{~cm}$ & $\begin{array}{l}\text { Fresh, dark brown, nutty, compacted, fine porous, } \\
\text { roots, root impressions, heavy loamy, the transition is } \\
\text { by change in coloration. }\end{array}$ \\
\hline $\mathrm{B}_{2} 59-117 \mathrm{~cm}$ & $\begin{array}{l}\text { Fresh, brown, nutty, compacted, fine porous, black } \\
\text { brown inclusions, humus lacquer on aggregate facets, } \\
\text { loamy, transition by presence of carbonates and change } \\
\text { in coloration. }\end{array}$ \\
\hline $\begin{array}{l}\mathrm{B}_{\mathrm{Ca}} \\
\mathrm{cm}\end{array}$ & $\begin{array}{l}\text { Fresh, light brown, instable nutty, compacted, black } \\
\text { brown inclusions, rare roots, carbonates in the form of } \\
\text { loose yellow straw agglomerations with a diameter } \\
\text { from 3 to 10 mm, medium loamy, gradual transition. }\end{array}$ \\
\hline $\mathrm{C}_{\mathrm{Ca}}>150 \mathrm{~cm}$ & $\begin{array}{l}\text { Fresh, non-uniform coloration, yellow brown, } \\
\text { compacted, fine porous, black brown inclusions, rusty } \\
\text { ocherish leather coats, carbonates in the form of loose } \\
\text { agglomerations, medium loamy. }\end{array}$ \\
\hline
\end{tabular}

Gray forest soils of Western Siberia, despite being covered with forests, underwent active reclamation, as they usually are combined with chernozems and located in bog-free territories along large rivers. The first settlers inhabited these territories. Until now, the gray forest soils of wet interfluves are used as grassland if at all. The gray forest soils are characterized with favorable physical, chemical and hydrophysical properties, making them similar to chernozems. The average thickness of humus horizon in $26 \mathrm{~cm}$ allows creating a full-scale plowed horizon, while the humus content of $5.9 \%$ allows getting good crop yields.

Rational agricultural use of gray forest soils would first require correct determination of their classification. In the areas that were plowed several decades ago it is hard to do using the classic morphological attributes, as annual mechanical treatment changes the appearance and properties of the humus layer. That is why we need to use only the genetic horizons that were left untouched by human activity. Primarily, it pertains to the presence of silicon earth powdering on aggregate facets. Despite anthropogenic changes in the humus horizon, this morphological attribute stays noticeable for a long time. In the plow pan horizon (deeper than $30 \mathrm{~cm}$ ), it is possible to see humus lacquer on aggregate facets. It is an attribute of solodization in the gray forest soil. It may be used to register changes in this process when involving the gray forest soils in farming. Minute traces of humus lacquer in the plow pan and a large amount of amorphous silica earth in the plowed horizon will be a proof of increased solodization of the gray forest soil. It will be a signal to make a decision to conserve the soil by changing its anthropogenic load.

Another important morphological attribute of gray forest soils that may hint on soil processes during the agricultural use is the boiling line (the upper boundary of calcium carbonate proliferation) and the form of newly formed carbonates..
If large carbonates are above the mean boiling line, it is a reliable attribute of increased leaching of soil by descending water currents. For gray forest soils of Western Siberia it will inevitable lead to their acidification and increased podzolization. It is also a signal to change the land use system on such soils.

\section{CONCLUSION}

Gray forest soils of Western Siberia differ from similar soils of the European part of Russia by their morphogenetic attributes. The soil profile is characterized by a clear differentiation of genetic horizons, with intensity depending on a subtype and increasing when moving from dark gray to light gray soils. Thickness of the humus eluvial horizon depends not only on soil subtype, but on its formation conditions as well. The humus layer in the dark gray forest soils may reach $38 \mathrm{~cm}$ in thickness. The highest variability in the humus layer thickness is observed in gray forest soils, which leads to non-uniform fertility within the boundaries of a single parcel of arable land. Depth of carbonate occurrence also varies significantly, even within the same subtype. In solodized gray forest soils, the illuvial-carbonate horizon may vary within the range of $60-120 \mathrm{~cm}$, while in podzolized soils it may appear at a depth of larger than 1 meter. The most reliable morphological attributes of the anthropogenically transformed gray forest soils are presence of new formations and inclusions in the plow pan, which together with the morphological attributes of the plowed horizon will help classify gray forest soil and find out whereto the modern soil formation is directed.

\section{References}

[1] D.T. Degefie, E. Fleischer, O. Klemm, A.V. Soromotin, O.V. Soromotina, A.V. Tolstikov and N.V. Abramov, "Climate extremes in south western Siberia: past and future" Stoch. Environ. Res. Risk Assess. 28 (2014), pp. 2161-2173. DOI: 10.1007/s00477-014-0872-9.

[2] N. Ustinov, A. Maratkanov and A. Martynenko, "Experimental study of the parameters of the active tool of a cultivator with a frame in form a flexible tubular element", MATEC Web of Conferences, 106, 2017, pp. 08063. DOI: https://doi.org/10.1051/matecconf/201710608063

[3] M.A. Chasovshchikova, O.M. Sheveleva, M.A. Svjazhenina, N.I. Tatarkina, A.V. Satkeeva, A.A. Bakharev, E.A. Ponomareva and A.G. Koshchaev, "Relationship between the genetic variants of kappa-casein and prolactin and the productive-biological characteristics of cows of the black-motley breed", Journal of Pharmaceutical Sciences and Research, 9, 2017, pp. 1038-1044.

[4] A. Lyubimova and D. Eremin, "Laboratory varietal control as a guarantee of successful work of gribusiness in Russia," MATEC Web of $\begin{array}{llll}\text { Conferences, } 170, & \text { 2018, } & & \end{array}$ https://doi.org/10.1051/matecconf/201817004015

[5] V. Sapega, G. Tursumbekova, "Yielding ability and adaptability parameters of cereal crop varieties in the forest steppe of Northern Transuralia," Russ. Agric. Sci. 36, 2010, pp. 160-165, 10.3103/S1068367410030031.

[6] Y.P. Loginov, A.A. Kazak, L.I. Yakubyshina, T.N. Falaleeva, S.N. Yashchenko and E.T. Yarova, "Breeding value of collection varieties of potato in the forest-steppe zone of the Tyumen region," Journal of Pharmaceutical Sciences and Research, 1, 2018, pp. 377-380.

[7] D. Eremina, "IT-technologies in soil Informatics and Russian agribusiness," MATEC Web of Conferences, 170, 2018, pp. 04016. DOI: https://doi.org/10.1051/matecconf/201817004016 
[8] D. Eremina, "IT-technologies in soil Informatics and Russian agribusiness", MATEC Web of Conferences, 170, 2018, pp. 04016. DOI: https://doi.org/10.1051/matecconf/201817004016

[9] D. Eremina, "The impact of transport infrastructure on ecological status of arable land in Western Siberia", MATEC Web of Conferences, 170, 2018, pp. 05004. DOI: https://doi.org/10.1051/matecconf/201817005004

[10] Field determinant of Russian soil, M., 2008, 182 p.

[11] N.A. Gruzdeva, S.G., Katchenko and D.I. Eremin, "Dynamics of the content and reserves of humus in agrocery forest soils of Northern Zauralye", Fertility, vol. 3, 2017, pp. 16-19.

[12] D.I. Eremin, "The use of modern data about the composition and properties of soil for the development of transport infrastructure of Tyumen" IOP Conference Series: Earth and Environmental Science, 2017, vol. 90, Conf. 1. DOI: org/10.1088/1755-1315/90/1/012021.

[13] D.I. Eremin, "Changes in the content and quality of humus in leached chernozems of the Trans-Ural forest-steppe zone under the impact of their agricultural use," Eurasian soil science, 2016, 5, pp. 538-545. DOI: $10.1134 / \mathrm{S} 1064229316050033$

[14] B.E. Chizhov, A.M. Shishkin and O.A. Kulyasova, "Succession of living ground cover in Scots pine crops, created on the felling of mixed birch forest-steppe of Western Siberia," Bulletin of the Altai state agrarian University, vol. 3, 2016, pp. 96-102.
[15] A.V. Iglovikov, "The development of artificial Phytocenosis in Environmental Construction in the far North," Procedia Engineering, vol. 165, 2016, pp. 800-805. DOI:10.1016/j.proeng.2016.11.778.

[16] A.V. Iglovikov, "The development of artificial Phytocenosis in Environmental Construction in the far North", Procedia Engineering, 165, 2016, pp. 800-805. DOI:10.1016/j.proeng.2016.11.778.

[17] D.I. Eremin, "The dynamics of agrophysical properties of the arable chernozem under the effect of many years use of mineral fertilizers in the forest-steppe zone of Zauralye", Agrophysics, vol. 2, 2018, pp. 9-14. DOI: 10.25695/ARPH.2018.02.02

[18] I. Kuhling, D. Redozubov, G. Broll and D. Trautz, "Impact of tillage, seeding rate and seeding depth on soil moisture and dryland spring wheat yield in Western Siberia", Soil \& Tillage Research, 2017, 170, pp. 43-52. DOI: 10.1016/j.still.2017.02.009

[19] D. I. Eremin and N. A. Gruzdeva, "The influence of anthropogenic factor on microaggregate composition of gray forest soils," Siberian Bulletin of agricultural science, 1, 2018, pp. 28-37. DOI: 10.26898/0370-8799-2018-1-4

[20] N.A. Gruzdeva and D.I. Eremin, "Phosphate regime of arable gray forest soils of Northern Urals", Agrochemical Bulletin, 5, 2017, pp. 12-15

[21] N. V. Perfiliev and O.A. Musina, "Parameters of dark-grey forest soil at long application of various systems of the basic processing", Agriculture, 2, 2016, pp. 23-25. 